\title{
The Quill Pen in a Funeral Oration: Clément Marot Appropriates the Ancient Genre
}

\author{
IRINA DZERO
}

Kent State University

Cet article examine comment Clément Marot s'approprie le genre du discours funèbre. L'auteur y montre que sa Deploration de Florimond Robertet et son Eglogue sur Louise de Savoie n'obéissent pas aux modèles classiques et chrétiens du discours funèbre. Le poète crée plutôt une combinaison inventive des deux modèles. Suivant les règles du discours funèbre classique, le sujet est d'abord louangé en tant qu'individu unique. Suivant le modèle chrétien, son caractère individuel est ensuite estompé au profit du chrétien bon et humble. En juxtaposant la vie dans les mémoires et la vie dans le paradis chrétien, Marot laisse ses lecteurs libres de choisir selon leur sensibilité. En effet, le narrateur, qui pourrait pousser le lecteur à choisir entre les approches humaniste et évangélique, refuse de le faire. Au lieu de cela, il promeut la classe naissante des intellectuels dont il fait clairement partie.

$\mathrm{T}$ The two "funeral orations" by Clément Marot considered in this article are remarkably eclectic. Marot brings together both the Christian and the classical models of this ancient genre. Celebrating Evangelism and Humanism, the poet also puts them to use to celebrate himself and his fellow writers. In his orations, Christianity and classical humanism debate whether the person praised in the oration must be affirmed as a unique individual or erased as a perfect Christian. ${ }^{1}$ The narrator, instead of arbitrating between these two traditions, defends a cause of his own. In contrast to the impersonal speakers we encounter in traditional models of the funeral orations, Marot's narrator is a personable and self-aware composer, the homo scribens. Without committing himself either to the individualized terrestrial immortality of the classical humanists or to the anonymous bliss in heaven of the Christians, the homo scribens promotes the continuity of fellow intellectuals, who, here on earth as in heaven, have a special space just to themselves. 


\section{Funeral oration as a genre: from Antiquity to the Renaissance}

The genre of the funeral oration has a long history, a well-established structure, and conventional themes. Its two major components are the lament and the consolation. ${ }^{2}$ The lament identifies the individual by his or her achievements and character. Having praised the individual and lamented the loss of so excellent a person, the speaker of the oration proceeds to comfort the audience for this loss. In Western literature the funeral oration develops along two principal models: the classical and the Christian. Appropriating this genre, Marot chooses to use them both, even though they seem to exclude each other.

Let me begin by describing the distinctive traits of the classical funer-

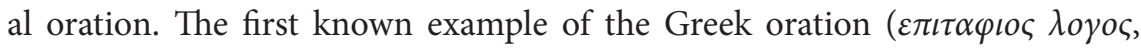
epitáphios logos) is Pericles' Funeral Oration, a fragment of Thucydides' History of the Peloponnesian Wars (431 BCE). The speaker celebrates the Athenian soldiers fallen in the battle with the Corinthians, but he focuses on the city of Athens and all its citizens saying, "We are unique." ${ }^{3}$ The genre becomes increasingly popular among the Romans, who considered that not only heroes, but also remarkable persons are entitled to an oration: "the Athenians thought that no one except soldiers should be conspicuous in death. The Romans, on the other hand, believed that this honor should be accorded all distinguished citizens, whether they had been commanders of campaigns or had otherwise aided the state either in a magistracy or by giving wise counsel; not only to men who had died in their boots, but also to those who died in their beds."

Cicero's popular dialogue On Friendship is a good example of the Roman funeral oration (laudatio funebris). One of the speakers, Laelius, lost his best friend, Scipio Africanus. When he is asked to talk about Scipio, Laelius identifies his friend by his specific achievements and talents. Scipio was so wise that he was elected consul twice, and the first time before reaching the required age for applicants to this position. Scipio's military genius allowed Rome to defeat her foes, Carthage and Numantia. He proved his generosity by providing for his disinherited mother. His rich obsequies show that he was greatly loved and respected by the Roman citizens. Laelius adds that although Scipio died young, he had enough time to show the extent of his talents, a fact that should console his friends and admirers. Identifying Scipio by specific character traits and 
achievements, Laelius restores him to life and preserves him for posterity. The example of Scipio's "triumph and exultation"5 inspires the audience to model themselves on this worthy person, as well as to appreciate and make the most of their terrestrial life. This feature of the Roman laudatio funebris appeals to the Roman historian Polybius. He describes how the Roman funeral oration creates the community of the forever alive by urging the young to do something worthy and become a part of this community. Polybius writes:

\begin{abstract}
By this means, by this constant renewal of the good report of brave men, the celebrity of those who performed noble deeds is rendered immortal, while at the same time the fame of those who did good service to their country becomes known to the people and a heritage for future generations. But the most important result is that young men are thus inspired to endure every suffering for public welfare in the hope of winning the glory that attends on brave men. ${ }^{6}$ (Book VI, chapters 53-54)
\end{abstract}

Thus, the goal of the classical funeral oration is twofold. First, it identifies and praises the individual. Second, it presents the individual as a worthy example to follow, inspiring the audience to appreciate this earthly life and to attempt to become as worthy as the subject of the oration has been.

In contrast, in the Christian funeral oration (the second model available to Marot) the focus shifts from the individual to the blessed life in Paradise, thus obliterating the person praised in the oration. A good example of the Christian funeral oration is Saint Augustine's speech on the death of his mother Monnica in Book IX of the Confessions. Augustine praises Monnica for being humble, so humble that she never reproached her cheating and abusive husband, "not in deed only, but not even in word" (bk 9, ch. 19). ${ }^{7}$ What is more, she advised other abused wives to follow her example and be obedient to their husbands. Similarly, it is by "observance and persevering endurance and meekness" that Monnica won over her abusive mother-in-law (bk 9, ch. 20). Monnica never gossiped about others (bk 9, ch. 21). Paradoxically, the only feature that makes Augustine's mother memorable is not an achievement, but a failing (which she later corrected): the love of wine. Thus, Monnica is represented as praiseworthy for what she did not do (did not object, did not resist violence, did not talk about others), rather than for what she did do. 
Monnica's personality and the life that she has lived are presented in conformity with the Christian doctrine, which makes it difficult to identify her by means of unique features or deeds. The individual cannot be identified by praiseworthy features and deeds because these must be ascribed to God, as "No one is good but God alone" (Mk 10.17-18). The individual can be described with bad features and deeds, of course. However, these do not fit the purpose of the oration, which is, indeed, to praise the individual. Thus, the predicament of the Christian writer who composes a funeral oration is the necessity to praise the individual without the tools for praising him or her. The orations by Saint Ambrose and Gregory of Nazianzen will illustrate this predicament. To our surprise, the two different individuals praised by these two Church Fathers become almost exactly identical.

The fourth-century archbishop of Constantinople, Gregory of Nazianzen, praises his sister Gorgonia by describing what she did not do: she did not stare or listen to satisfy her curiosity, did not laugh, did not make a fashion statement with her clothes, did not chatter, and, after an accident, she did not send for a doctor because the only physician she trusted was God. The sole goal of Gorgonia's life was to dissolve herself in God. "Who had such control over her eyes? Who so derided laughter that the very beginning of a smile seemed almost too much for her? Who so barred the portals of her ears? ... Who so regulated her lips?" (pp. 106-107, my emphasis) ${ }^{8}$ "Hers were no costly, flowing, diaphanous robes, hers no brilliant and beautiful gems, flashing colour round about and causing the figure to glow with light" (107, my emphasis); "who spoke less, confining herself within the womanly bounds of piety?" (108); "she would have no physician save Him who had permitted the accident" (111, my emphasis); "she longed to be dissolved, for she had great confidence in Him who called her" (115), and finally, "she was dissolved, or, better, taken to God" (116). Thus, throughout the oration Gorgonia is presented as remarkable not by what she did, but by what she did not do. She restrained and controlled her individuality. In exactly the same way does Ambrose, fourth-century bishop of Milan, erase the personality of his brother Satyrus. Satyrus could compete with a child in simplicity and modesty: "his simplicity was so marked that, having become a child, as it were, he radiated the simplicity of that innocent age and was conspicuous as a living image of perfect virtue and as a mirror of blameless life" (pp. 183-84, my emphasis). ${ }^{9}$ He was also continent, frugal, and just: "He shrank no less from obscene speech as from bodily impurity" (184), "he loved continence 
so much that he never sought a wife" (184, my emphasis); "he did not want to recover anything except his own"; "he never enjoyed elaborate meals or dinner with many courses" (185, my emphasis).

In these orations, the two distinct individuals-Gorgonia, the sister of Gregory, and Satyrus, the brother of Ambrose-become almost identical: worthy of praise because they did not listen, talk, or have. Because Christian authors have no means of praising the individual and thus of diversifying the lament part of the oration, their rhetorical goldmine is the consolation, or the blessed life in Paradise. Gregory and Ambrose extol the future life in Paradise and disparage this terrestrial life as full of misery and uncertainty.

Let us now turn to sixteenth-century Northern Europe. In the 1530s, when Clément Marot composes his orations, Evangelical and Lutheran ideas are competing in influence with humanism. While sharing a common philological and didactic impetus, these movements sharply differ on the conception of the individual. The humanists promote the unique individual, ${ }^{10}$ while the Reformers emphasize human sinfulness. Accordingly, when Martin Luther writes his Funeral Sermon on the Elector Duke John of Saxony (1532), he devotes to the person of the Elector only a few paragraphs. And even this handful of lines, instead of identifying and praising the subject of the oration, obliterates him as a person. "I shall not praise him now for his great virtues, but rather let him remain a sinner like all the rest of us," writes Luther. "Therefore I am not going to make out that our beloved lord was altogether pure, though he was a very devout, kindly man, free of all guile, in whom never in my lifetime have I seen the slightest pride, anger, or envy, who was able to bear and forgive all things readily and was more than mild." ${ }^{11}$ Because the Elector is a sinful human being, Luther refuses to identify him by unique positive traits. Even when praised, the Elector's person dissolves in goodness and kindness and becomes even more vague and forgettable. Only in the consolation part of the oration about God's infinite grace does Luther regain his unsurpassed exuberance and eloquence. In other words, the person of the Elector is subservient to Luther's own teachings expressed in the oration. Alternatively, the humanist funeral oration shifts the focus from the Christian consolation back to the individual. For example, Guillaume Cretin, one of the "grands rhetoriqueurs," praises the individual for excelling in writing, in arms, in the knowledge of ancient languages, in beauty, and in gracious manners ("Complaint on the death of the late Guillaume de Bissipat, Seigneur d'Aneches, Viconte de Falaise"12). Consider also Two Funeral 
Sermons on Francis I (1547) by Pierre de Chastel, the French humanist and court bishop. In both orations, de Chastel speaks exclusively about the individual whom he praises: the illustrious king of France. The writer identifies Francis as a wise philosopher king (p. 36), ${ }^{13}$ athlete (15), restorer and student of ancient languages (19), philosophy, and history (23), and an unsurpassed poet (24). He consoles his listeners with the idea that this great king will enjoy the life everlasting ("perpetuelle memoire" p. 56) in the memory of his grateful subjects, the French people. Thus, Renaissance authors draw inspiration from two competing models. As Erwin Panofsky notes, reaffirming or erasing the individuality of the subject of their oration, authors inspire enthusiasm for this life, or for the life to come. ${ }^{14}$ In contrast, Marot's orations, commemorating the intellectual Florimond Robertet and the queen mother Louise of Savoy, are quite unique. The poet puts the classical and the Christian models in conversation with each other.

\section{Marot's oration on the Secretary of State, Florimond Robertet}

La Deploration de Florimond Robertet (1527) stages a fierce debate between the classical and the Christian models of the funeral oration. The two champions who represent humanism (République Françoise) and Evangelism (la Mort) exchange long speeches and nearly come to blows, and the narrator (the original "Acteur" was replaced with "Autheur" in subsequent editions) finds himself in the midst of the argument. Although we expect the narrator to mediate between the classical and the Christian models of the funeral oration, he disappears when one champion cedes the floor to the other, at the exact midpoint of the poem. I would argue that the narrator's disappearance pursues two goals. His first goal is to avoid committing himself once and for all to either humanism or Christianity. His second goal is to identify himself with the subject of the oration, the fellow intellectual Florimond Robertet who also disappears at the midpoint of the poem. Celebrating both himself and Robertet as masters of the quill pen, the narrator saves both Robertet and himself from death and oblivion. In describing first himself, then the fellow intellectual by means of the quill pen, the narrator takes this symbolic baton from him and replaces him in the community of the forever alive. Thus, giving the classical and the Christian 
models of the funeral oration their due, the Renaissance poet Marot uses them to promote a cause of his own: the emergent class of intellectuals.

The narrator begins by reflecting on his light and amusing style of writing and the need to abandon it in order to write a sad poem. He is nostalgic and personable. Note that the first word of the poem is "pen" ("Jadis ma plume ..." v.1)..$^{15}$ It is by the same word- "plume" - that the narrator will identify Florimond Robertet, the subject of his oration. It is intriguing that the narrator is in no hurry to identify Robertet, or even to reveal his name. We are not allowed to discover Robertet's identity until we read a 50-line riddle. The narrator invites the audience to guess the profession of the deceased from his coat of arms, which represents a black wing on a golden band. This long riddle, building on the symbolism of the wing, could in fact describe any intellectual. Plato's Phaedrus, immensely popular in the Renaissance, gives us a hint as to why Marot chose the wing as the emblem of the intellectual. In Phaedrus the wing represents the human soul and its ability to rise above the terrestrial and reach the divine. Plato writes: "The wing is the corporeal element which is most akin to the divine, and which by nature tends to soar aloft and carry that which gravitates downwards into the upper region, which is the habitation of the gods." ${ }^{16}$ Thus, the wing is the necessary attribute of every noble soul. Such a soul traverses the heavens to reach the realm inhabited by the divine intelligence, "the colourless, formless, intangible essence, visible only to the mind, the pilot of the soul." ${ }^{17}$ The souls incapable of soaring into the sky and partaking of the divine intelligence lose their wings and fall to the ground. But the individual to whom Marot devotes his oration never had to fear such a lot. His soul, "wing without a match" ("Esle sans per à elle" v. 127), used to fly as it should have ("a vollé ainsi, que voller faut" v. 129): soaring between the two airs, not too high and not too low ("Entre deux Airs, ne trop bas, ne trop hault" v. 130), around the wide world ("Circonvollant ce Monde spacieux" v. 133), and traversing the nine skies ("survollant maintenant les neufs Cieulx" v. 134). According to the cosmography of the period (see Figure 1), beyond the nine skies it is God that one finds. 


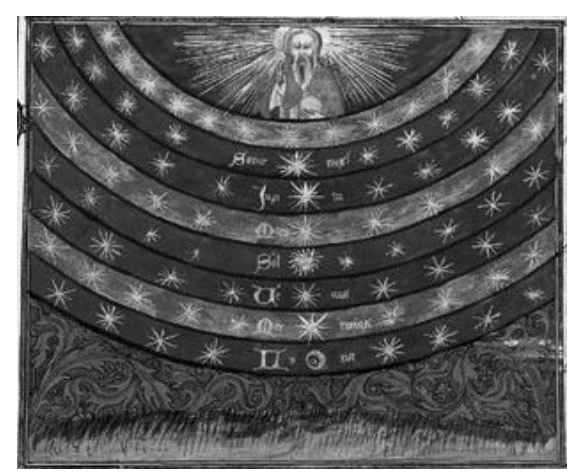

Figure 1. Nicole Oresme, Le Livre du Ciel et du Monde, Paris, $1377^{18}$

Ancient geocentric models (such as the Ptolemaic) number eight heavens, which are the spheres of the planets. There are seven planetary spheres: Moon, Mercury, Venus, Sun, Mars, Jupiter, and Saturn. The eighth sphere is the starry firmament. To these eight spheres medieval theologians added a ninth in which they placed God. Figure 1, the illustration from Nicole Oresme's Livre du ciel et $d u$ monde (1377), shows eight concave spheres surrounding the ninth sphere, the abode of God. In the Divine Comedy (Paradiso, Canto XXX) Dante also adds to the seven spheres of the planets and to the starry firmament a ninth sphere, the abode of the angels. Dante's narrator traverses the nine spheres and rises to the realm inhabited by God, the realm called the Empyrean. Thus, just like Plato's winged soul, the individual whom Marot represented by a wing traverses the nine skies in order to join the divine intelligence. It is difficult to find a description of the intellectual more generic than Marot's. As a riddle supposed to give a key to the identity of the deceased Robertet it is hardly helpful. Any composer-poet, writer, diplomat, or philosopher-could be described in such terms.

The topic of the wing leads to that of the quill pen. The heraldic wing sheds a quill. From now on, it is the quill pen that will continue to designate the mysterious subject of the oration and his profession. This was a quill pen that wrote better than any other pen of the century ("la mieux escrivant / Plume, qui fut de nostre aage vivant" vv. 137-38). This was a quill pen that taught contemporary writers how to write ("C'est celle Plume, où modernes espritz / (Soubz ses patrons) leur sçavoir ont appris” vv. 139-40). Thus, the riddle of the quill 
pen is as generic as the riddle of the wing. Apart from the indication that this quill pen served kings in their secrets ("servir en leurs secretz les Roys" v. 143), any composer, any intellectual could be so described.

Only in the conclusion of his riddle does the Narrator reveal the name of the person represented by his coat of arms. The name of the deceased is Florimond Robertet, the first Secretary of State and councilor of the King. ${ }^{19}$ In this office, which the French king Francis I created especially for him, Robertet succeeded to manage the wild expenses of the court and to achieve financial stability despite incessant wars. ${ }^{20}$ Robertet also promoted humanism and invited to France numerous Italian intellectuals and artists. Indeed, Robertet was Marot's own benefactor, and the narrator calls him "the person from whom he expected an income" ("Celluy ... / Par où guettoys ma fortune prospere" vv. 163-64). Thus, in the riddle of the wing and the quill pen the Narrator identifies Robertet as a statesman, humanist, and intellectual who knew the worth of fellow intellectuals, and their need for payment. At the same time, this riddle is extraordinarily generic, indicating that the poet attempted to describe any representative of the new class of intellectuals and make them aware of their common identity.

The narrator finishes his speech by describing the two champions who will speak about Robertet. The champion of humanism is République Françoise, or the French Republic, a dignified and sad lady. The champion of evangelism is la Mort, Death, depicted as a black and horrifying creature accompanied by an equally black and frightening raven. In the course of his speech, the narrator identifies with Robertet by means of three textual links. It is by means of the quill pen that the narrator described himself in the beginning of his speech, and that Robertet is described. The second link between them is Death's weapon. The narrator relates to us that Death nearly killed him with the same dart with which she killed the statesman and Marot's patron, Robertet ("Et a bien peu qu'elle ne ma rué / Le mesme Dard, dont elle avoit tué / Celluy ... / Par où guettoys ma fortune prospere" vv. 161-64). The third link is their common disappearance at exactly the same time. The narrator as personable individual with opinions, feelings, and admiration for fellow intellectuals - the person we have met at the beginning of the poem-disappears exactly in the middle of the poem, and so does Florimond Robertet.

After describing the disputants, the French Republic and Death, the narrator steps into the shadows, and the first disputant, the French Republic, deliv- 
ers her oration about Robertet. This character is the champion of Renaissance humanism, and her oration is modeled on the classical pattern. The French Republic praises Robertet for his various achievements and for his service to his country. In contrast to the narrator, the French Republic is much more specific in her oration. She exalts Robertet the writer ("main tant imitable" "so imitable a hand" v. 221), Robertet the advisor to kings ("l'homme en conseil expert" "the man expert in giving advice" v. 186), and a man of great erudition ("le Chef, qui tant sçavoit" "the head that knew so much" v. 225). She praises Robertet's contribution to the humanistic revival, the financial stability of the country and his concern for the poor, "le Cueur tant charitable" 'so charitable a heart' v. 224). The French Republic hurls insults at Death and accuses her of stealing her best servants. Thus, in the first part of the poem Marot reenacts the classical lamentation: he identifies and praises Robertet. The consolation following the lament is also classical: the French Republic affirms that the unique individual Robertet will endure forever in the memory of posterity ("un cler renom... sans fin triumphera" vv. 227-28).

The French Republic cedes the floor to Death, the champion of Christianity, and the Narrator reappears. We expect the Narrator to cheer the praise of Robertet delivered by the French Republic. Instead, we encounter a dispassionate voice in which it is impossible to recognize the enthusiastic author of the riddle of the quill pen. The very word "I" will no more appear in the poem, except for the two concluding lines. The narrator disappears without letting us know whether he agrees with the humanistic mode of representing the individual, or whether he prefers the evangelical mode that is about to follow.

Because the champion of Evangelism, Lady Death, takes the floor, Florimond Robertet as a personable individual also disappears from the poem. According to the requirements of the Christian funeral oration, Lady Death does not speak about the person of Robertet but delivers an evangelical sermon instead. Lady Death paints life and the individuals who enjoy it in a dismal light. According to her, life is more bitter than bile ("amere plus que fiel" v. 304), because it is full of iniquity and suffering. The people who enjoy living their life impiously prefer their pleasures and themselves to God. And the longer one lives, the more sinful one becomes ("Plus tu y vis, plus te charges de crimes" v. 306). It is impossible to live without sinning, and it is impossible to do enough good works to deserve God's mercy ("I'homme ne peult faire / Qu'il puisse vivre icy bas sans peché, / Jamais ne peult envers Dieu satisfaire” vv. 349-51). 
Only God's grace, the gift of living faith ("vive foy" v. 355), can save the sinner. ${ }^{21}$ One must therefore welcome Death because she helps transition one from the valley of tears to Paradise. Burial ceremonies, commemorations, laments are at best illogical. Instead of weeping and talking about how distinguished the individual was, one should rejoice. As good as a person was when alive, he or she was still a sinner. In contrast, in Paradise this person will enjoy a worry-free and guilt-free existence.

Again, one would expect the narrator who resumes speaking to express at least some sentiment, some appraisal of the speech delivered by Death. But the narrator returns as impassible as he showed himself to be after the speech of the French Republic. The narrator's "I"- with which the reader could identify-does not reappear to lend his support to either humanism or evangelism. Instead of declaring which champion he agrees or disagrees with, the Narrator reports how other listeners received the sermon by which Death erased the individual Florimond Robertet. No living creature is in a hurry to give Death a warm welcome. On the contrary, sensing her approach, animals, birds, worms, and fishes all run away in panic (vv. 461-84). People act no better than irrational and soulless animals: they run away, hide in their homes, and shut the gates of the cities (vv. 485-96). In addition to avoiding a speedy ascent to Paradise, people continue to hold in high regard both life and the individual. When the funeral cortege arrives at its destination, Blois, everyone comes out to pay their last respects to Florimond Robertet, the great servant of France and of the French people.

Why did the Narrator disappear at the exact midpoint, verse 277 of the 555-verse poem? He disappears when the readers need him the most, to help them arbitrate the conflict between the French Republic and Death. Which champion is the reader to choose, Renaissance humanist or Evangelist? Which model of the funeral oration appeals more to the Renaissance poet, the classical or the Christian?

We cannot say with confidence whether the narrator identifies with the French Republic or Death. It is probable that it is Marot himself who refuses to take sides: his support of both humanism and Evangelism is well known. Yet, there is someone with whom the narrator does identify without reservations: it is the fellow intellectual Florimond Robertet. Recall that three links exist between them: they are both described by means of the quill pen; the narrator is threatened with the same weapon Death used to killed Robertet 
(v. 162); both Robertet and the Narrator disappear in the middle of the poem, when one champion cedes the floor to the other (v. 277). Robertet has no choice but to disappear: the goal of the Christian funeral oration is not to identify a personable individual but to expose evangelical doctrine. But the concomitant Narrator's disappearance is strategic. On the one hand, it betrays his reluctance to arbitrate between humanism and Evangelism. On the other hand, it shows the narrator's desire to identify with Robertet. The living narrator symbolically replaces the fallen comrade. The champions of the poem each have a cause to defend, and the Narrator, similarly, has his own cause. The French Republic promotes the individual, terrestrial life and active service to the community, while Death denies the individual and promotes the life to come. As for the narrator, he promotes the concept of the ever-living homo scribens. The narrator, who is alive and well, takes the quill pen, the common symbol and tool of all intellectuals, from Robertet, who can no longer put it to use.

Thus, in Marot's poem intellectuals pass the quill pen over to each other, symbolizing the class of the intellectual elite. Desiderius Erasmus, the intellectual celebrity of the Northern Renaissance, called by his contemporaries "the prince of humanists," wrote a poem about his own pen and its travels from one owner to another, The Reed Pen Speaks (Calamus loquitur ${ }^{22}$ ). Erasmus received this pen from a German humanist, Johann Reuchlin, and then presented it to his disciple Wilhelm Nesen, another German humanist and educator. In this manner, the pen changes hands three times, immortalizing its masters:

The reed pen speaks.

Little reed pen that I am, I wrote so many large volumes all by myself, though I was guided by the finger joints of Erasmus. The Nile produced me, Reuchlin gave me to Erasmus, and now, honorably discharged, I belong to Wilhelm. And he preserves me as sacred to the Muses and dedicated to Apollo, a dear token of eternal friendship, lest $I$, who made so many names known to posterity, names never to be wiped out in the long course of time, should perish in obscurity. 
This pen made famous Reuchlin, Erasmus, and Nesen. As a gift circulating among them, the pen is more than a token of friendship. By this gift the giver recognizes the recipient as the fellow homo scribens and admits him to the community of the forever alive.

\section{Marot's oration on the queen mother, Louise of Savoy}

The instrument of composition also travels between artists in the second oration written by Marot. This work praises Louise of Savoy, the mother of Francis I and Margaret the queen of Navarre. Louise, the subject of the oration, is not an intellectual. How then could the instrument of composition change hands? To ensure the exchange Marot introduces two composers in this oration. Here, as in the poem about Florimond Robertet, both the classical and the Christian models are present. But this time they are not in conflict. Putting aside their differences, they allow artistic composition to promote itself for an entire onethird of the poem. The Funeral Oration On My Lady Louise of Savoy (Eglogue sur le trespas de ma dame Loyse de Savoye, mere du roy Françoys, premier de ce nom, 1531 ${ }^{23}$ is an eclogue. What will become of the quill pen and of the composer-intellectual in this oration? The bucolic genre transforms the composer into a shepherd and the quill pen into a flute. One of the composers will improvise for his comrade the oration about the queen mother. The performer has an incentive: his friend promises to reward him with a special double flute which has cost him a young goat ("un double Chalumeau / ... / Lequel (à peine) ay eu pour ung Chevreau” vv. 41-43).

Both components of the oration - the lament and the consolation-combine classical and Christian elements. Thus, the performing shepherd identifies the queen mother by her specific achievements. It was she who ruled France during the Spanish captivity of her son, King Francis I. It was she who protected the country from foreign invasions during the absence of the king ("on n'a point veu les Loups y faire entrée" v. 148). It was also she who returned the king to France by arranging a peace treaty with Spain (Treaty of Cambrai, 1529), for which achievement the poet calls her the Shepherdess of Peace ("Bergere de la Paix" v. 240). But this praiseworthy queen disappears in the Christian part of the lament, when the speaker starts praising her for generic virtues: goodness, morality, and industriousness. The "very good" ("la tresbonne" v. 254) Louise 
managed well her household ("Son beau mesnage en bon sens conduysoit" v. 66). She lectured to the young ladies in her care on laziness-the mother of all vice ("Il faut preveoir que Vice ne difforme / Par long repos vostre aage Florissant. / Oisiveté n'allez point nourrissant" vv. 75-77). Thus, the lament is at once classical and Christian, and so is the consolation. On the one hand, the composer urges people to honour the memory of Louise whose qualities increased the prestige of her country ("Venez ... / Pour faire honneur à celle, qui valoir / Feit par son los son Pays" vv. 218-220). On the other hand, the composer recommends no sadness. Louise is now in Paradise where she lives without fear, disquiet, or anxiety ("sans peur, peine, ou mesaise" v. 203).

Which model of the funeral oration ultimately has the upper hand, the classical or the Christian? What kind of a person was the queen mother, Louise of Savoy? These questions hardly matter to the poet. His two shepherds, who play in tandem the role of the homo scribens, are more fascinated with the art of composition and performance than with the person of Louise of Savoy. The poem abounds in words connoting performance, such as "chanter" (vv. 4, 29, $33,50,189,247,266)$, "sonner [le chalumeau]" (vv. 43 and 256), "chansons" (vv. 9 and 18), "chant" (v. 256), and such tools of performance as the following flutes: "Goy", "Holette", "Fonde" (244); "Chalumeau" (vv. 32, 41, 255); "flageol" (v. 270). To conclude his oration, the performer claims his reward: "Delivre moy le Chalumeau promis" (v. 254). The delighted comrade is happy to deliver it, wishing that he had a laurel crown ("vert Laurier" v. 272) to add to the prize. Overwhelmed with feeling, he confesses that the song about the death of the queen mother moved him even more than the event itself ("mon coeur tu contraicts / A se douloir plus qu'il n'a de coustume” vv. 263-64). An entire onethird of the poem ( 80 lines out of 276) is devoted to the power of art. The homo scribens, in this poem the composite figure formed by the duo of composers, is a living and cheerful counterpart to the deceased queen mother. Bodily life may be brought to stillness, yet the intellectual life, symbolized by the travelling flute and the quill pen, cannot be put to a stop.

Marot introduces the homo scribens and the travelling quill pen in the genre of the funeral oration because he, too, is on a quest for timelessness. Classical authors promote individualized life in the memory of posterity. Christian authors promote anonymous happiness in Paradise. Marot promotes a renewal and continuity of the intellectual life. In fact, in his imagination, intellectuals reunite in a Paradise reserved exclusively for them. This is why Marot's Lament 
on the Death of Guillaume Preudhomme (1543) ${ }^{24}$ has no somberness or sadness, contrary to what the title would suggest. This short poem does not take up the antagonism between the Christian and classical notions of the individual that we have observed in the two orations discussed above. Indeed, the individual in question and what he did matter little. The ascent of the king's financial advisor to heaven describes the Paradise of the intellectuals. Upon his arrival, Preudhomme begs to be admitted into the group of celestial elite ("leslite des champs / Elisiens" 'elite of the Elysian Fields' vv. 20-21), consisting of the best French poets and intellectuals, such as Jean Lemaire de Belges, Guillaume Budé, Guillaume de Lorris, and others. Marot places himself on the waiting list to join this group as one of the three best living French poets. The new applicant Preudhomme was not a poet but Secretary of the Treasury and advisor to the king. But, above all, he loved the things of the mind, which is why, when he arrives in Paradise, he expresses no desire to join his fellow financiers. When intellectuals ask him why he wants to join them rather than the group of the influential and powerful, he answers that he seeks joy, repose, and knowledge, which are to be found only among intellectuals ("Je cherche joye, et repos, et sçavoir, / Où les peult on mieulx qu'entre vous avoir?” vv. 60-62). Needless to say, the flattered celestial elite grants the clandestine intellectual Preudhomme permission to join them.

Marot's funeral orations on Louise of Savoy and Florimond Robertet illustrate how the attitude toward the individual evolves in the Renaissance. These poems draw on two contradictory models of the funeral oration, the classical and the Christian. Classical humanists identify the individuals whom they commemorate by unique traits and achievements, and comfort the audience with the assurance that these worthy persons will continue living in the memory of posterity. The Church fathers praise individuals for the generic virtues of humbleness and modesty, and console by suggesting that these excellent Christians will continue living in Paradise. The double standard according to which Marot commemorates Louise of Savoy and Florimond Robertet reveals the influence of both models. Listing the specific achievements of the queen mother and of the king's councilor, the poet affirms that they will always be remembered for their specific achievements. At the same time, the poet dissolves the personality of the persons he commemorates when he exalts their humbleness and recommends that they rejoice that they are now in Paradise. The composer-narrator figure could have helped the reader to arbitrate between 
these two traditions. Instead, this figure becomes a persona in his own right and defends his own cause. Representing the newly emerging class of intellectuals, the narrator-composer desires to assure its prestige and permanence in time. The composer-active, living and present-symbolically replaces the individual praised in the oration, whom death rendered absent and passive. The eternity and continuity of intellectual life compensate for the temporality and finitude of the terrestrial life.

\section{Notes}

1. Existing studies identify these works as little more than a reworking of the medieval fixed poetic form complainte: see C. A. Mayer, Clément Marot (Paris: A. - G. Nizet, 1972), pp. 153-160, or George Joseph, Clément Marot (Boston: G. K. Hall \& Company, 1985), p. 71. In addition, no studies sufficiently emphasize the interaction of humanist and evangelical arguments in these works. For example, Gérard Defaux and M. A. Screech (their appraisals will be quoted below) meticulously examine the evangelical component of the poems but disregard the equally important humanist component.

2. See Martin R.P. McGuire, “The Early Christian Funeral Oration," in Funeral Orations by Saint Gregory Nazianzen and Saint Ambrose, The Fathers of the Church: A New Translation 22 (Washington D.C.: The Catholic University of America Press, 1988), p. viii.

3. Thucydides, History of the Peloponnesian War, trans. Rex Warner (London: Penguin Classics, 1972), p. 147.

4. O. C. Crawford, "Laudatio Funebris," The Classical Journal 37. 1 (1941), p. 21.

5. Marcus Tullius Cicero, "On Friendship," in On Old Age. On Friendship. On Divination, trans. W.A. Falconer, Loeb Classical Library 154 (Cambridge, Mass.: Harvard University Press, 1923), pp. 119-20.

6. Polybius, The Histories of Polybius, trans. W.R. Paton, Loeb Classical Library 131 (Cambridge, Mass: Harvard University Press, 1997), bk VI, ch. 53-54.

7. Augustine, Confessions, trans. E.B. Pusey (Cambridge, Mass.: Harvard University Press, 1968).

8. Saint Gregory Nazianzen, "On His Sister, St. Gorgonia," in Funeral Orations by Saint Gregory Nazianzen and Saint Ambrose, trans. Leo P. McCauley, Fathers of the 
Church: A New Translation, vol. 22 (Washington, D.C.: The Catholic University of America Press, 1988), pp. 101-19.

9. Saint Ambrose, "On His Brother, Satyrus," in Funeral Orations by Saint Gregory Nazianzen and Saint Ambrose, trans. C.S. Sullivan, Fathers of the Church: A New Translation, vol. 22. (Washington, D.C.: The Catholic University of America Press, 1988), pp. 161-97.

10. Some twentieth-century historians argued that the ideas of the Antiquity were not taken to heart by Renaissance humanists. For example, Peter Partner said that for the sixteenth-century philologists themselves, "Humanism was not an ideological programme but a body of literary knowledge and linguistic skill based on the 'revival of good letters,' which was a revival of a late-antique philology and grammar." In Partner's opinion, humanists saw no conflict between Christianity and paganism, and Burckhardt was wrong "to describe humanism in unqualified terms as 'pagan,' and thus help[ing] precipitate a century of infertile debate about the possible existence of something called 'Christian humanism' which ought to be opposed to 'pagan humanism"' (Peter Partner, Renaissance Rome, Portrait of a Society, 1500-1559 [Berkeley: University of California Press, 1979] pp. 14-15). Partner argued that Burckhardt offered his rebirth of the anthropocentric thought in the Renaissance with "no substantial proof,"(15)] without, of course, offering any substantial proof to the contrary. In some ways, it is as difficult to refute Burckhardt as it is to refute Partner. Hopefully the present article can convince Burckhardt's opponents that Renaissance philologists took pagan anthropocentric thought quite seriously, and that they did perceive it to be in conflict with theocentric medieval Christianity. In Marot's poems these thoughts enter into a dialogue, negotiate their differences, and fail to come to a consensus.

11. Martin Luther, Sermons, Luther's Works 51 (Philadelphia: Muhlenberg Press, 1959), p. 236, emphasis added.

12. Guillaume Cretin, "Complaincte sur la mort de feu Guillaume de Bissipat, Seigneur d'Aneches, Viconte de Falaise," in Les Poésies de Guillaume Cretin (Paris: Coustelier, 1723), pp. 51-71. In contrast to Marot's orations, the evangelical component is barely present in Cretin's funerary works.

13. Pierre du Chastel, Deux Sermons funèbres prononcez es obsequies de François premier de ce nom, ed. Pascale Chiron (Genève: Droz, 1999).

14. Studying the evolution of the tomb sculpture, Panofsky argues that during the classical era, funeral art focused on the past life of the individual and was "retrospective." Christian sculptors turned to the future life of the person in Paradise 
and created "prospective" art. The funeral art of the Renaissance shows a return to the classical "retrospective" mode. See Studies in Iconology: Humanistic Themes in the Art of the Renaissance (New York: Harper \& Row, 1972), p. 83. Philippe Ariès describes the same evolution and adds that the Renaissance tomb sculpture also returns to the realistic portrayal of the individual as opposed to the idealized portrayal practised by medieval artists. See The Hour of Our Death (New York: Knopf, 1981), p. 47.

15. All references to this poem are from Clément Marot, "Deploration sur le trespass de messire Florimond Robertet," in Euvres poétiques complètes, ed. Gérard Defaux (Paris: Bordas, 1990), pp. 207-23.

16. Plato, "Phaedrus," in The Dialogues of Plato, trans. Benjamin Jowett (New York: Random House, 1924), p. 251.

17. Plato, p. 252.

18. Paris, BnF, Fr. 565, fo 69.

19. C. A. Mayer writes that under Charles VII, Louis XII, and François I Robertet "more or less fulfilled the functions of the prime minister," in Clément Marot (Paris: Editions A.-G. Nizet, 1972), p. 35.

20. Louis Batiffol, The Century of the Renaissance, trans. E. F. Buckley (London: W. Heinemann, 1916), p. 375.

21. This hallmark of the evangelical doctrine motivated M.A. Screech to study the poem exclusively as the expression of Marot's evangelism, "the very heart of evangelism, both traditional and reforming," in Clément Marot: A Renaissance Poet Discovers the Gospel (Leiden: Brill, 1994), p. 63. Gérard Defaux also considers the work as purely evangelical. Similarly, Melanie E. Gregg concludes that Marot has made his choice in favour of Evangelism: "Even Marot, who makes every effort to elicit tears in the beginning of the poem, completely rejects the notion of grief by the time he reaches the end. The turning point takes place as Marot considers the foolishness and the hypocrisy of mourning. He affirms that such behavior is not befitting to believers in Christ," writes Gregg in "Women's Poetry of Grief and Mourning: The Languages of Lament in Sixteenth-Century French Lyric," in Response to Death: The Literary Work of Mourning, ed. by Christian Riegel (Alberta: University of Alberta Press, 2003), p. 58. In contrast, George Joseph expresses a doubt that evangelical speech of Lady Death should be taken at face value. He reflects "whether (1) we should listen to Death's words because they come from biblical commonplaces popular among the evangelists or (2) suspect them because of the intentions of the hideous personification who puts them forth" ("Paradox in 
Marot, Lemaire and Ronsard," in The Shaping of Text: Style, Imagery and structure in French Literature, ed. Emmanuel J. Mickel Jr. [Cranbury, NJ: Associated University Press, 1993], p. 64).

22. Desiderius Erasmus, "The Reed Pen Speaks," in Poems, trans. Clarence H. Miller, Collected Works of Erasmus 85 (Toronto: University of Toronto Press, 1993), pp. 135-36, my emphasis.

23. All references to this work are from Clément Marot, "Eglogue sur le trespas de ma dame Loyse de Savoy", in CEuvres poétiques complètes, ed. Gérard Defaux (Paris: Bordas, 1990), pp. 224-31.

24. All references to this work are from Clément Marot, "Complainte de Monsieur le General, Guillaume Preudhomme”, in CEuvres poétiques complètes, ed. Gérard Defaux, vol. 2 (Paris: Bordas, 1990), pp. 387-91. 
